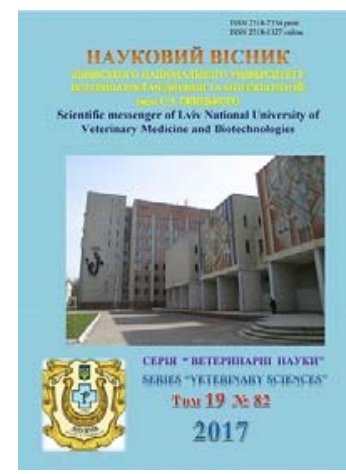

Науковий вісник Львівського національного університету ветеринарної медицини та біотехнологій імені С.З. Гжицького

Scientific Messenger of Lviv National University of Veterinary Medicine and Biotechnologies

doi:10.15421/nvlvet8215

ISSN 2518-7554 print

ISSN 2518-1327 online

$\underline{\text { http://nvlvet.com.ua/ }}$

УДК 619:577.12:616.391

\title{
Біохімічні показники крові свиноматок за профілактики порушень обміну мінеральних речовин
}

\author{
Н.Г. Грушанська, В.М. Костенко \\ grushanska_ng@nubip.edu.ua \\ Національний університет біоресурсів і природокористування Украӥни, \\ вул. Полковника Потехіна, 16, м. Київ, 03041, Украӥна
}

\begin{abstract}
3 усіх домашніх тварин свині найбільше страждають від дефіциту мінеральних речовин. Це зумовлено специффікою свинарства, технологією годівлі, утримання та анатомо-фізіологічними особливостями свиней. Для отримання кращих якостей продукиії свинарства необхідно проводити корекцію раціонів для свиней різних технологічних груп, використовуючи мінеральні кормові добавки, які враховують не тільки фізіологічні потреби в мінералах відповідних вікових груп $і$ класів свиней, а й біогеохімічну зону або провіниію, де розтамоване господарство, а також умови, які супроводжують виникнення дефіциту. Розроблення нових екологічно чистих, не токсичних засобів профілактики порушень обміну мінеральних речовин у свиней є перспективним напрямом ветеринарної медицини.

Дослідження проводились у господарстві Київської області (північно-східна біогеохімічна зона). Біохімічні показники крові досліджували на біохімічному аналізаторі «Labline-010» стандартними наборами реактивів. Вміст хімічних елементів у воді досліджували методом атомно-емісійної спектрометрії на приладі Optima 210 DV.

У роботі викладені матеріали власних досліджень авторів щодо визначення біохімічного статусу організму лактуючих свиноматок в північно-східній біогеохімічній зоні Украйни за профілактики мікроелементозів з використанням нових експериментальних екологічно чистих засобів.

Досліджено вміст загального білка, альбумінів, глюкози, Кальцію загального, Фосфору неорганічного, холестеролу, білірубіну, активність АЛТ, АСТ, ЛФ в сироватиі крові лактуючих свиноматок північно-східної біогеохімічної зони України до і після застосування експериментальних препаратів. Установлено позитивний вплив профілактичних засобів на показники обміну білків та Кальиію.

У сироватиі крові свиноматок периої дослідної групи на 28 добу досліду встановлено нижчий на 5,3\% вміст загального білка та вищий на 16,5\% Кальцію загального, порівняно з контрольною групою тварин.

У сироватиі крові свиноматок другої дослідної групи на 28 добу вміст загального білка був нижчим на 8,3\%, а концентрація Кальцію загального вища на 19,9\% порівняно з контрольною групою тварин.

Ключові слова: свиноматки, кров, біохімічні показники, лактачія, профілактичні засоби, профілактика, обмін речовин
\end{abstract}

\section{Биохимический статус свиноматок при профилактике нарушений обмена минеральных веществ}

\author{
Н.Г. Грушанская, В.М. Костенко \\ grushanska_ng@nubip.edu.ua
}

Национальньй университет биоресурсов и природопользования Украинь, ул. Полковника Потехина 16, Киев, 03041, Украина

\begin{abstract}
Из всех домашних животных свиньи больше всего страдают от дефицита минеральных веществ. Это обусловлено спеиификой свиноводства, технологией кормления, содержания и анатомо-физиологическими особенностями свиней. Для получения лучших качеств продукции свиноводства необходимо проводить коррекциию рационов для свиней различных тех-
\end{abstract}

\section{Citation:}

Grushanska, N.G., Kostenko, V.M. (2017). The biochemical indicators of sows' blood at the prevention of mineral metabolic disorders. Scientific Messenger LNUVMB, 19(82), 71-76. 
нологических групп, используя минеральные кормовые добавки, которые учитывают не только физиологические потребности в минералах соответствуюших возрастных групп и классов свиней, но и биогеохимическую зону или провинцию, где находится хозяйство, а также условия, сопровождающие возникновение дефицита. Разработка новых экологически чисmых, нетоксичных средств профилактики нарушений обмена минеральных вешеств у свиней является перспективныл направлением ветеринарной медицины.

Исследования проводились в хозяйстве Киевской области (северо-восточная биогеохимическая зона). Биохимические показатели крови исследовали на биохимическом анализаторе «Labline-010» стандартными наборами реактивов. Содержание химических элементов в воде исследовали методом атомно-эмиссионной спектрометрии на приборе Ортіта 210 DV.

В работе изложены материаль собственных исследований авторов по определению биохимического статуса организма подсосных свиноматок в северо-восточной биогеохимической зоне Украины по профилактике микроэлементозов с использованием новых экспериментальных экологически чистых препаратов.

Исследовано содержание общего белка, альбуминов, глюкозы, кальция общего, фосфора неорганического, холестерола, билирубина, активность АЛТ, АСТ, ЩФ в сыворотке крови лактируюших свиноматок северо-восточной биогеохимической зоны Украины до и после применения экспериментальных препаратов. Установлено положительное влияние профилактических средств на показатели обмена белков и кальция.

В сыворотке крови свиноматок первой опытной группы на 28 сутки опыта содержание общего белка было ниже на 5,3\%, а кальция общего выше на 16,5\% по сравнению с контрольной группой животных.

В сыворотке крови свиноматок второй опытной группы на 28 сутки содержание общего белка было ниже на 8 , $3 \%$, а кальция общего выме на 19,9\% по сравнению с контрольной группой животных

Ключевые слова: свиноматки, кровь, биохимические показатели, лактачия, профилактические средства, профілактика, обмен веществ

\title{
The biochemical indicators of sows' blood at the prevention of mineral metabolic disorders
}

\author{
N.G. Grushanska, V.M. Kostenko \\ grushanska_ng@nubip.edu.ua \\ National University of life and environmental sciences of Ukraine,
Polkovnyka Potekhyna Str., 16, Kyiv, 03041, Ukraine
}

Of all domestic animals, pigs suffer the most from deficiency of minerals. This is due to the specificity of pig production, feeding technology, retention and anatomical - physiological characteristics of pigs. In order to obtain the best qualities of pig production, it is necessary to make correction the ration for swines of various technological groups using mineral feed additives that take into consideration not only the physiological needs for minerals of the corresponding age groups and classes of swines but also the biogeochemical zone or the province where the farm is located. Also, conditions that accompany the emergence of a mineral deficit are taken into account. The development of new, eco-friendly, non-toxic means of preventing disorders of metabolism of minerals in pigs is a promising direction of veterinary medicine.

The research was carried out ont the farm of the Kyiv region (northeastern biogeochemical zone). Biochemical parameters of blood were studied using biochemical analyzer «Labline-010» with standard sets of reagents. The content of chemical elements in water was investigated by the method of atomic emission spectrometry on the Optima $210 \mathrm{DV}$ device.

The paper presents the authors' own research on determining the biochemical status of an organism of lactating sows in the northeastern biogeochemical zone of Ukraine at the prevention of microelementosis using new experimental eco-friendly means.

The content of total protein, albumin, glucose, total calcium, inorganic phosphorus, cholesterol, bilirubin, activity of ALT, AST, $A F$ in the blood serum of sows of the northern-eastern biogeochemical zone of Ukraine before and after the application of experimental drugs was investigated. The positive influence of prophylactic agents on the parameters of metabolism of proteins and calcium was defined.

In the blood serum of the sows of the first experimental group, 28 days later, the total protein content on 5.3\% lower and the total calcium concentration on $16.5 \%$ higher than the control group of animals were found.

In the blood serum of sows in the second experimental group, 28 days later, the total protein content on $8.3 \%$ lower and the total calcium concentration on 19.9\% higher than the control group of animals were found.

Key words: sows, blood, biochemical indicators, lactation, prevention drugs, prevention, metabolism

\section{Вступ}

Патології обміну речовин в організмі свиней виникають у господарствах різних форм власності внаслідок порушення технології годівлі, умов утримання i дії на організм тварин стрес-факторів. Такі захворювання характеризуються масовістю, часто не мають чітких клінічних проявів і наносять значних економічних збитків свинарству (Sudakov et al., 1991; Bel'kevich, 2016).

3 усіх домашніх тварин свині найбільше страждають від дефіциту мінеральних речовин. Це зумовлено специфікою свинарства, технологією годівлі, утримання та анатомо-фізіологічними особливостями свиней. Для отримання якісної продукції свинарства необхідно проводити корекцію раціонів у свиней різних технологічних груп, використовуючи мінеральні кормові добавки, які враховують не тільки фізіологічні потреби в мінералах відповідних вікових груп і класів свиней, а й біогеохімічну зону або провінцію, де розташоване господарство, в якому вирощуються корми, а також умови, які супроводжують виникнення дефіциту (Sudakov et al., 1991). 
Сьогодні у ветеринарній медицині розроблено і використовується ряд засобів для профілактики патології мінерального обміну у тварин (Griban et al., 1988; Berkovich, 2007; Bereza et al., 2010; Sidorenko and Korneyev, 2010; Buchko et al., 2012; Nadeyev et al., 2012; Leont'yev and Kul'makova, 2012; Nadeyev et al., 2013; Platonov et al., 2016). До їх складу входять різні форми хімічних елементів, проте пошук екологічно чистих, нетоксичних і високоефективних форм профілактичних i лікувальних засобів, які позитивно впливають на метаболізм мінеральних речовин в організмі свійських тварин, є перспективним напрямом ветеринарної медицини.

Фізіологічна потреба організму свині в макро- i мікроелементах не може бути забезпечена лише споживаним кормом. Тому пошук щодо розроблення засобів, які застосовують для профілактики порушень обміну мінеральних речовин пероральним шляхом, триває.

Мета дослідження - дослідити біохімічні показники свиноматок за профілактики полігіпомікроелементозу 3 використанням нового препарату «Суілактомін-окси». Для досягнення мети необхідно було дослідити вміст загального білка, альбумінів, глюкози, Кальцію загального, Фосфору неорганічного, холестеролу, білірубіну, активність АЛТ, АСТ, ЛФ в сироватці крові свиноматок та оцінити вплив на вищезгадані показники і якість приплоду застосованих профілактичних засобів.

\section{Матеріал і методи досліджень}

Дослідження проводились у господарстві Філія «Антонов-Агро» (Васильківський район Київської області (північно-східна біогеохімічна зона); кількість свиней - 1500 голів; порода - метиси порід ландрас та дюрок; система утримання - станкова; відлучення поросят у 30 діб; тип годівлі - концентратний. Дослідні свиноматки були 2-3 опоросу, масою тіла 220-250 кг. Тварин поділили на 3 групи по 7 свиноматок у кожній. У першій групі свиноматки отримували основний раціон (контроль), у другій групі - додатково мінеральний препарат «Суілактомін» (Bereza et al., 2010), по 10 г на тварину, через добу, з кормом, протягом 28 діб (дослід 1), в третій групі - додатково отримували розроблений нами на основі результатів попередніх етапів досліджень екологічно чистий препарат «Суілактомін - окси», по 35 г на тварину, через добу, 3 кормом, протягом 28 діб (дослід 2). До складу препарату «Суілактомін - окси» входять лактатні сполуки Купруму, Цинку, Кобальту, бурштинова кислота, натрієва сіль гумінових кислот та глауконіт. Зразки крові у дослідних тварин відбирали зранку натще 3 вушної вени в одноразові пробірки, після попереднього клінічного огляду. Протягом 2 годин відібрані проби транспортували до лабораторії 3 використанням охолоджувальних елементів. Кров досліджували на біохімічному аналізаторі «Labline010» стандартними наборами реактивів. Хімічний склад води визначали методом атомно-емісійної спектрометрії на приладі Optima 210 DV фірми Perkin
Elmer. Також аналізували умови утримання і раціони годівлі свиноматок загальноприйнятими методиками.

\section{Результати та їх обговорення}

Клінічні показники свиноматок на першу добу досліду були в межах фізіологічних коливань. За основними показниками раціон годівлі свиноматок відповідав нормативам. За результатами дослідження зразків питної води господарства на вміст хімічних елементів встановлено характерний для північно-східної біогеохімічної зони дефіцит Кобальту $(<0,0002$ мг/л), Купруму $(<0,0003$ мг/л) та Цинку $(<0,0004$ мг/л). Нами також виявлено підвищений вміст Феруму в 57 разів $(17,11$ мг/л) у зразках питної води згідно 3 нормами СанПін 2.1.4.559096, WHO та СС (МДК 0,3 мг/л), тому додаткове застосування цього елементу у складі профілактичних засобів, на нашу думку, було недоцільним.

Відомо, що показники крові тварин залежать від багатьох факторів (фізіологічний стан, раціон, продуктивність тощо). Нами досліджено основні показники крові, які відображають стан обмінних процесів в організмі тварин. У сироватці крові свиноматок на першу добу досліду біохімічні показники за середніми значеннями перебували в межах фізіологічних величин (табл. 1). Проте в окремих тварин вміст загального білка, сечовини та \% альбумінів були на верхній, а концентрація Кальцію загального - на нижній фізіологічній межі. Такі зміни характерні за концентратного типу раціону і свідчать про порушення обміну білків та Кальцію в організмі свиноматок.

В організмі тварин Кальцій впливає на такі функції: утворення кісток і зубів, скорочення м'язів, згортання крові, проникність клітин, продукцію молока, функції нервової системи тощо. За дефіциту Кальцію в організмі свиней проявляються такі симптоми: втрата апетиту, уповільнений ріст і розвиток, кульгавість, крихкість кісток, погіршення відтворення, тетанія. Для профілактики порушень і корекції обміну Кальцію в організмі свиней використовують джерела мінеральних речовин: подрібнений вапняк, гіпс і мінеральні добавки Са і Р - монокальційфосфат, дикальцийфосфат, трикальційфосфат, кісткове борошно та інші моно- і полідобавки, премікси в дозах відповідно до класу, віку й маси тіла свиней.

На 28 добу досліду у сироватці крові свиноматок контрольної групи, порівняно 3 першою добою досліджень, спостерігались тенденції до зростання вмісту загального білка та зниження коефіцієнту де Рітіса (табл. 1, 2). Причиною зростання вмісту загального білка у свиноматок контрольної групи може бути високий його вміст у кормах раціону. Коефіцієнт де Рітіса $є$ діагностичним маркером патології печінки i його зниження свідчить про порушення функціонального стану печінки (Sidorenko and Korneyev, 2010).

На 28 добу досліду у сироватці крові свиноматок першої дослідної групи вміст загального білка мав тенденцію до зниження (на 5,3\%), а концентрація Кальцію загального була на 16,5\% вища за цей показ- 
ник у тварин контрольної групи (табл. 2) $(\mathrm{P}<0,05)$. Показники, які відображають функціональний стан печінки і нирок і обмін Са та Р залишились у межах фізіологічних величин. Тенденція до зниження вмісту загального білка в сироватці крові свиноматок за застосування препарату «Суілактомін», очевидно, мо- жна пояснити позитивним впливом його на обмін білків, підтвердженням чого $є$ тенденції до зростання відносного вмісту альбумінів та зниження вмісту сечовини.

Біохімічні показники крові свиноматок на першу добу досліду, $M \pm m, n=7$

\begin{tabular}{|c|c|c|c|c|}
\hline \multirow{2}{*}{ Показник } & \multirow{2}{*}{$\begin{array}{c}\text { Фізіологічні } \\
\text { межі }\end{array}$} & \multicolumn{3}{|c|}{ Група тварин } \\
\hline & & контроль & дослід 1 & дослід 2 \\
\hline \multirow{2}{*}{$\begin{array}{l}\text { Загальний білок, г/л } \\
\mathrm{Lim} \\
M \pm m\end{array}$} & $70-85$ & & & \\
\hline & & $\begin{array}{c}74,1-85,5 \\
80,56 \pm 1,57\end{array}$ & $\begin{array}{c}76,5-88,7 \\
81,00 \pm 1,90\end{array}$ & $\begin{array}{c}72,4-88,0 \\
79,91 \pm 3,34\end{array}$ \\
\hline \multirow{2}{*}{$\begin{array}{l}\text { Альбуміни, г/л } \\
\operatorname{Lim} \\
M \pm m\end{array}$} & $28-47$ & & & \\
\hline & & $\begin{array}{c}31,0-35,0 \\
32,84 \pm 0,73\end{array}$ & $\begin{array}{c}31,0-34,8 \\
32,27 \pm 0,65\end{array}$ & $\begin{array}{c}30-41 \\
32,91 \pm 1,40\end{array}$ \\
\hline \multirow{2}{*}{$\begin{array}{l}\text { Альбуміни, \% } \\
\operatorname{Lim} \\
M \pm m\end{array}$} & $35-45$ & & & \\
\hline & & $\begin{array}{l}36,84-45,21 \\
40,85 \pm 1,08 \\
\end{array}$ & $\begin{array}{l}38,33-42,18 \\
39,88 \pm 0,62 \\
\end{array}$ & $\begin{array}{c}34,09-47,07 \\
34,09 \pm 47,07\end{array}$ \\
\hline \multirow{2}{*}{$\begin{array}{l}\text { Глюкоза, ммоль/л } \\
\operatorname{Lim} \\
M \pm m\end{array}$} & $2,5-3,9$ & & & \\
\hline & & $\begin{array}{c}1,85-3,68 \\
2,94 \pm 0,21\end{array}$ & $\begin{array}{c}1,89-3,78 \\
3,01 \pm 0,21\end{array}$ & $\begin{array}{c}1,80-3,74 \\
2,96 \pm 0,24\end{array}$ \\
\hline \multirow{2}{*}{$\begin{array}{l}\text { Сечовина, ммоль/л } \\
\text { Lim } \\
M \pm m\end{array}$} & $3,3-6,0$ & & & \\
\hline & & $\begin{array}{c}2,1-6,2 \\
3,83 \pm 0,72 \\
\end{array}$ & $\begin{array}{c}2,8-6,1 \\
4,09 \pm 0,60\end{array}$ & $\begin{array}{c}2,7-6,2 \\
3,97 \pm 0,66\end{array}$ \\
\hline \multirow{2}{*}{$\begin{array}{l}\text { Кальцій загальн., ммоль/л } \\
\operatorname{Lim} \\
M \pm m\end{array}$} & $2,5-3,25$ & & & \\
\hline & & $\begin{array}{c}2,2-3,0 \\
2,64 \pm 0,16\end{array}$ & $\begin{array}{c}2,1-2,9 \\
2,51 \pm 0,12\end{array}$ & $\begin{array}{c}2,3-3,1 \\
2,67 \pm 0,13\end{array}$ \\
\hline \multirow{2}{*}{$\begin{array}{l}\text { Фосфор неорг., ммоль/л } \\
\text { Lim } \\
M \pm m\end{array}$} & $1,45-2,1$ & & & \\
\hline & & $\begin{array}{c}1,38-1,72 \\
1,60 \pm 0,05\end{array}$ & $\begin{array}{c}1,44-1,76 \\
1,62 \pm 0,05\end{array}$ & $\begin{array}{c}1,44-1,99 \\
1,71 \pm 0,05\end{array}$ \\
\hline \multirow{2}{*}{$\begin{array}{l}\text { Білірубін загальн., мкмоль/л } \\
\text { Lim } \\
M \pm m\end{array}$} & $0,0-6,84$ & & & \\
\hline & & $\begin{array}{c}0,02-0,2 \\
0,11 \pm 0,03 \\
\end{array}$ & $\begin{array}{c}0,05-0,1 \\
0,09 \pm 0,01\end{array}$ & $\begin{array}{c}0,02-0,2 \\
0,12 \pm 0,03\end{array}$ \\
\hline \multirow{2}{*}{$\begin{array}{l}\text { ЛФ, Од/л } \\
\operatorname{Lim} \\
M \pm m\end{array}$} & $30-150$ & & & \\
\hline & & $\begin{array}{c}17,5-109,4 \\
68,24 \pm 12,76\end{array}$ & $\begin{array}{c}17,5-99,6 \\
65,66 \pm 11,08\end{array}$ & $\begin{array}{c}17,0-109,6 \\
70,20 \pm 17,79\end{array}$ \\
\hline \multirow{2}{*}{$\begin{array}{l}\mathrm{ACT}, \text { Од/л } \\
\operatorname{Lim} \\
M \pm m\end{array}$} & $10-35$ & & & \\
\hline & & $\begin{array}{c}14,3-39,9 \\
24,13 \pm 2,71 \\
\end{array}$ & $\begin{array}{c}12,4-39,8 \\
22,40 \pm 3,41\end{array}$ & $\begin{array}{c}14,3-39,9 \\
21,29 \pm 1,97\end{array}$ \\
\hline \multirow{2}{*}{$\begin{array}{l}\text { АЛТ, Од/л } \\
\text { Lim } \\
M \pm m\end{array}$} & $5-20$ & & & \\
\hline & & $\begin{array}{c}14,9-20,8 \\
17,96 \pm 1,36\end{array}$ & $\begin{array}{c}12,0-22,8 \\
16,66 \pm 1,74\end{array}$ & $\begin{array}{c}12,2-19,4 \\
15,90 \pm 1,34\end{array}$ \\
\hline \multirow[t]{2}{*}{ Коефіцієнт де Рітіса } & $0,91-1,75$ & & & \\
\hline & & $\begin{array}{c}0,87-1,92 \\
1,34 \pm 0,15\end{array}$ & $\begin{array}{c}1,03-1,75 \\
1,32 \pm 0,13\end{array}$ & $\begin{array}{c}1,07-1,81 \\
1,35 \pm 0,11\end{array}$ \\
\hline \multirow{2}{*}{$\begin{array}{l}\text { Холестерол загальн., ммоль/л } \\
\text { Lim } \\
M \pm m\end{array}$} & $1,56-2,86$ & & & \\
\hline & & $\begin{array}{c}1,8-2,6 \\
2,13 \pm 0,14\end{array}$ & $\begin{array}{c}1,7-2,8 \\
2,20 \pm 0,17\end{array}$ & $\begin{array}{c}2,0-2,6 \\
2,26 \pm 0,08\end{array}$ \\
\hline
\end{tabular}

Порівняно 3 першою добою дослідження в сироватці крові свиноматок першої дослідної групи був достовірно вищим вміст Кальцію загального на $23,5 \%(\mathrm{P}<0,05)$, що можна пояснити ефективними для його засвоєння формами у складі препарату «Суілактомін».

На 28 добу досліду в сироватці крові свиноматок другої дослідної групи вміст загального білка був нижчим на $8,3 \%(\mathrm{P}<0,05)$, а Кальцію загального вищий на $19,9 \% \quad(\mathrm{P}<0,05)$ порівняно 3 вищенаведеними показниками тварин контрольної групи. Одночасно зі зниженням вмісту загального білка встановлено підвищення відносної концентрації альбумінів. Відомо, що альбуміни виконують в організмі транспортну функцію, в тому числі і для макро- i мікроелементів, що може свідчити про стимуляцію обміну альбумінової фракції білків і позитивний вплив застосованого експериментального препарату «Суілактомін-окси». Показники сироватки крові, які відображують функціональний стан печінки і нирок свиноматок другої групи залишились в межах фізіологічних величин.

Порівняно 3 першою добою дослідження в сироватці крові свиноматок другої дослідної групи був достовірно вищий вміст Кальцію загального на $19,5 \%$ (Р $<0,05)$, що можна пояснити ефективними 
для його засвоєння сполуками у складі препарату «Суілактомін-окси».

За якістю приплоду найкращі показники були у групи свиноматок, яким застосовували експериментальний препарат «Суілактомін-окси» (табл. 3). Так, середньодобові прирости маси тіла у поросят, які народжені від свиноматок 2-ї дослідної групи, були більшими на $31 \%$, а у поросят $1-і$ дослідної групи - на 21\% порівняно 3 контролем. Гострі розлади травлення часто супроводжують «критичні» періоди росту та розвитку поросят i спостерігаються у них 321 доби життя та в період відлучення (Lukashchuk and Slívíns'ka, 2015). У поросят дослідних груп під час застосування засобів гострих розладів травлення порівняно 3 тваринами контрольної групи не виявляли.

Таблиия 2

Біохімічні показник крові свиноматок на 28 добу досліду, $M \pm m, n=7$

\begin{tabular}{|c|c|c|c|c|}
\hline \multirow{2}{*}{ Показник } & \multirow{2}{*}{$\begin{array}{l}\text { Фізіоло- } \\
\text { гічні межі }\end{array}$} & \multicolumn{3}{|c|}{ Група тварин } \\
\hline & & контроль & дослід 1 & дослід 2 \\
\hline \multirow{2}{*}{$\begin{array}{l}\text { Загальний білок, г/л } \\
\operatorname{Lim} \\
M \pm m\end{array}$} & $70-85$ & & & \\
\hline & & $\begin{array}{c}83,1-92,3 \\
86,14 \pm 2,42\end{array}$ & $\begin{array}{c}75,6-86,5 \\
81,57 \pm 1,66\end{array}$ & $\begin{array}{c}70,5-86,5 \\
78,96 \pm 2,13 *\end{array}$ \\
\hline \multirow{2}{*}{$\begin{array}{l}\text { Альбуміни, г/л } \\
\operatorname{Lim} \\
M \pm m\end{array}$} & $28-47$ & & & \\
\hline & & $\begin{array}{c}29,2-38,1 \\
32,10 \pm 1,29\end{array}$ & $\begin{array}{c}29,0-35,0 \\
32,43 \pm 1,07\end{array}$ & $\begin{array}{c}30,0-38,0 \\
33,14 \pm 1,27\end{array}$ \\
\hline \multirow{2}{*}{$\begin{array}{l}\text { Альбуміни, \% } \\
\operatorname{Lim} \\
M \pm m\end{array}$} & $35-45$ & & & \\
\hline & & $\begin{array}{l}32,89-38,99 \\
37,40 \pm 1,79 \\
\end{array}$ & $\begin{array}{l}33,53-42,68 \\
39,80 \pm 0,97 \\
\end{array}$ & $\begin{array}{l}36,72-46,86 \\
42,06 \pm 1,58\end{array}$ \\
\hline \multirow{2}{*}{$\begin{array}{l}\text { Глюкоза, ммоль/л } \\
\operatorname{Lim} \\
M \pm m\end{array}$} & $2,5-3,9$ & & & \\
\hline & & $\begin{array}{c}2,05-3,38 \\
2,89 \pm 0,23\end{array}$ & $\begin{array}{c}2,5-3,33 \\
3,01 \pm 0,11\end{array}$ & $\begin{array}{c}2,05-3,68 \\
3,07 \pm 0,20\end{array}$ \\
\hline \multirow{2}{*}{$\begin{array}{l}\text { Сечовина, ммоль/л } \\
\operatorname{Lim} \\
M \pm m\end{array}$} & $3,3-6,0$ & & & \\
\hline & & $\begin{array}{c}2,9-6,1 \\
4,46 \pm 0,54\end{array}$ & $\begin{array}{c}2,5-6,2 \\
3,91 \pm 0,68\end{array}$ & $\begin{array}{c}3,2-4,8 \\
3,76 \pm 0,23\end{array}$ \\
\hline \multirow{2}{*}{$\begin{array}{l}\text { Кальцій загальн., ммоль/л } \\
\operatorname{Lim} \\
M \pm m\end{array}$} & $2,5-3,25$ & & & \\
\hline & & $\begin{array}{c}2,3-2,9 \\
2,66 \pm 0,13\end{array}$ & $\begin{array}{c}2,9-3,5 \\
3,10 \pm 0,09 * \bullet\end{array}$ & $\begin{array}{c}2,8-3,6 \\
3,19 \pm 0,12 * \bullet\end{array}$ \\
\hline \multirow{2}{*}{$\begin{array}{l}\text { Фосфор неорг., ммоль/л } \\
\operatorname{Lim} \\
M \pm m\end{array}$} & $1,45-2,1$ & & & \\
\hline & & $\begin{array}{c}1,44-1,99 \\
1,76 \pm 0,07\end{array}$ & $\begin{array}{c}1,44-1,99 \\
1,73 \pm 0,06\end{array}$ & $\begin{array}{c}1,44-1,84 \\
1,65 \pm 0,07\end{array}$ \\
\hline \multirow{2}{*}{$\begin{array}{l}\text { Білірубін загальн., мкмоль/л } \\
\operatorname{Lim} \\
M \pm m\end{array}$} & $0,0-6,84$ & & & \\
\hline & & $\begin{array}{c}0,02-0,2 \\
0,10 \pm 0,02 \\
\end{array}$ & $\begin{array}{c}0,02-0,1 \\
0,07 \pm 0,02\end{array}$ & $\begin{array}{c}0,02-0,1 \\
0,08 \pm 0,01\end{array}$ \\
\hline \multirow{2}{*}{$\begin{array}{l}Л Ф, \text { Од/л } \\
\operatorname{Lim} \\
M \pm m\end{array}$} & $30-150$ & & & \\
\hline & & $\begin{array}{c}47,6-104,3 \\
87,96 \pm 10,06\end{array}$ & $\begin{array}{c}47,9-109,6 \\
78,57 \pm 8,76 \\
\end{array}$ & $\begin{array}{c}24,1-96,1 \\
58,50 \pm 13,12 \\
\end{array}$ \\
\hline \multirow{2}{*}{$\begin{array}{l}\text { АСТ, Од/л } \\
\operatorname{Lim} \\
M \pm m\end{array}$} & $10-35$ & & & \\
\hline & & $\begin{array}{c}13,9-28,2 \\
21,36 \pm 2,37 \\
\end{array}$ & $\begin{array}{c}18,9-34,5 \\
26,43 \pm 2,67\end{array}$ & $\begin{array}{c}13,3-27,6 \\
22,54 \pm 2,72 \\
\end{array}$ \\
\hline \multirow{2}{*}{$\begin{array}{l}\text { АЛТ, Од/л } \\
\operatorname{Lim} \\
M \pm m\end{array}$} & $5-20$ & & & \\
\hline & & $\begin{array}{c}11,8-21,7 \\
18,27 \pm 1,57 \\
\end{array}$ & $\begin{array}{c}11,1-28,5 \\
20,16 \pm 2,44\end{array}$ & $\begin{array}{c}10,2-20,8 \\
16,34 \pm 1,76\end{array}$ \\
\hline \multirow[t]{2}{*}{ Коефіцієнт де Рітіса } & $0,91-1,75$ & & & \\
\hline & & $\begin{array}{c}0,84-1,44 \\
1,23 \pm 0,09\end{array}$ & $\begin{array}{c}1,12-1,7 \\
1,35 \pm 0,07\end{array}$ & $\begin{array}{c}1,22-1,57 \\
1,37 \pm 0,04\end{array}$ \\
\hline \multirow{2}{*}{$\begin{array}{l}\text { Холестерол загальн., ммоль/л } \\
\operatorname{Lim} \\
M \pm m\end{array}$} & $1,56-2,86$ & & & \\
\hline & & $\begin{array}{c}1,6-2,3 \\
2,04 \pm 0,11 \\
\end{array}$ & $\begin{array}{c}1,5-2,3 \\
1,91 \pm 0,13\end{array}$ & $\begin{array}{c}0,8-2,3 \\
1,73 \pm 0,20 \bullet \\
\end{array}$ \\
\hline
\end{tabular}

Примітка: * $-\mathrm{P}<0,05$, порівняно з контролем, $\bullet-\mathrm{P}<0,05$, порівняно $з$ першою добою

Таблиця 3

Показники продуктивності свиноматок за якістю приплоду

\begin{tabular}{|l|c|c|c|}
\hline \multicolumn{2}{|c|}{ Показник } & \multicolumn{3}{|c|}{ Група тварин } \\
\cline { 2 - 4 } & контроль & дослід 1 & дослід 2 \\
\hline Кількість поросят на 1 добу, гол. & 78 & 77 & 73 \\
\hline Кількість поросят на 28 добу, гол. & 65 & 84,7 & 85,8 \\
\hline Маса поросят на 1 добу, кг & 85,8 & 467,2 & 54,25 \\
\hline Маса поросят на 28 добу, кг & 349,05 & 190 & 220 \\
\hline Середньодобовий приріст, г & 150 & 5,19 & 3,85 \\
\hline Загибель поросят (1-28 доба), \% & 16,67 & & \\
\hline
\end{tabular}


Отже, профілактика порушень мінерального обміну у лактуючих свиноматок виявилась найбільш ефективною в результаті використання препарату «Суілактомін-окси» за показниками білкового i кальцієво-фосфорного обмінів та якістю приплоду.

Сьогодні пошук нових екологічно чистих та не токсичних лікувально-профілактичних засобів у ветеринарній медицині триває. Питання щодо впливу нового експериментального препарату «Суілактомінокси» на клінічні, морфологічні, імунологічні показники та мінеральний обмін свиноматок потребує подальшого дослідження.

\section{Висновки}

1. Уміст загального білка, альбумінів, глюкози, Кальцію загального, Фосфору неорганічного, холестеролу, білірубіну, активність АЛТ, АСТ, ЛФ в сироватці крові свиноматок до застосування профілактичних засобів перебували в межах фізіологічних величин.

2. У сироватці крові свиноматок першої дослідної групи за застосування препарату «Суілактомін» на 28 добу досліду вміст загального білка був нижчим на 5,3\%, а Кальцію загального - вищим на 16,5\% (P < $0,05)$ порівняно 3 показниками тварин контрольної групи. Показники, які відображають функціональний стан печінки і нирок, були в межах фізіологічних величин.

3. У сироватці крові свиноматок другої дослідної групи за застосування препарату «Суілактомін-окси» на 28 добу вміст загального білка був нижчим на 8,3\% (P $<0,05)$, а Кальцію загального - вищим на 19,9\% $(\mathrm{P}<0,05)$ порівняно 3 показниками тварин контрольної групи. Показники, які відображають функціональний стан печінки і нирок, були в межах фізіологічних величин.

4. У поросят, які народжені від свиноматок другої дослідної групи, середньодобові прирости були на $31 \%$ вищі, а у поросят першої дослідної групи - на $21 \%$ вищі порівняно 3 тваринами контрольної групи.

Перспективи подальших досліджень. Перспективним $€$ розроблення і застосування у ветеринарній медицині та тваринництві нових екологічно чистих, нетоксичних засобів, які виробляються 3 вітчизняної сировини. Питання щодо впливу нових експериментальних препаратів на клінічні, морфологічні, імунологічні показники та мінеральний обмін свиноматок у різних біогеохімічних зонах України потребує подальшого дослідження.

\section{Бібліографічні посилання}

Bel'kevich, I.A. (2016). Poligipomikroelementozy zhivotnykh. RVZH SKHZH, 1, 24-28 (in Russian).

Berkovich, A.M. (2007). Primeneniye guminovykh i guminopodobnykh preparatov $\mathrm{V}$ veterinarii $\mathrm{i}$ meditsine, 29. http://www. humipharm. ru/research/ prim.pdf (in Russian).

Platonov, V.V., Larina, M.A., Dmitriyeva, Ye.D. (2016). Biologicheski aktivnyye meditsinskiye preparaty na osnove sapropelevogo guminovogo kompleksa. Vestnik novykh meditsinskikh tekhnologiy. 2, 11-20 (in Russian)

Buchko, O.M., Saliga, N.O., Svarchevs'ka, O.Z., Maksimovich, Í.Y. (2012). Gematologíchní pokazniki porosyat za dîi gumínovoï dobavki. Veterinarna bíotekhnologíya, 21, 201-205 (in Ukrainian).

Nadeyev, V.P., Chabayev, M.G., Nekrasov, R.V. (2013). Vliyaniye dobavki Biopleks zhelezo na produktivnost' i gematologicheskiye pokazateli podsosnykh svinomatok. Izvestiya Orenburgskogo gosudarstvennogo agrarnogo universiteta, 4(42), 139142 (in Russian).

Nadeyev, V.P., Chabayev, M.G., Nekrasov, R.V., Kliment'yev, M.I. (2012). Vliyaniye organicheskikh form mikroelementov na biokhimicheskiye pokazateli krovi suporosnykh svinomatok. Izvestiya Nizhnevolzhskogo agrouniversitetskogo kompleksa, 3 (27), 1-6 (in Russian).

Griban, V.G. Chumak, V.O., Garashchuk, M.Í. (1988). Vikoristannya oksigumatu z metoyu korektsií obmínu rechovin ta profílaktiki zakhvoryuvaností molodnyaka sviney. Veterinarna meditsina Ukraïni, 6, 16-17 (in Ukrainian).

Leont'yev, L.B., Kul'makova, N.I. (2012), Biologicheski aktivnyy kompleks dlya korrektsii metabolizma svinomatok. RVZH SKHZH, 2, 11-12 (in Russian).

Lukashchuk, B.O., Slívíns'ka, L.G. (2015). Vplyv fítobíotyka na gematologíchní pokaznyky pídsysnykh porosyat ta yikh zberezheníst' za nezaraznykh khvorob shlunkovo-kishkovogo traktu. Naukoviy vísnik LNUVMBT ím. S.Z. Gzhits'kogo. 17, 2(62), 287-293 (in Ukrainian).

Sudakov, M.O., Bereza, V.I., Pogursky, I.G. (1991). Microelementosis of farm animals. Kyiv, Urozhaj (in Ukrainian).

Bereza, V.Í., Dul'nêv, P.G., Tsvílíkhovs'kiy, M.Í., Sitníchenko, L.V., Grushans'ka, N.G. (2010). Kompleksniy preparat ta yogo zastosuvannya dlya profílaktiki porushen' míneral'nogo obmínu ta aktivatsií promízhnogo obmínu u goduyuchikh svinomatok. Patent Ukrainy na vinakhíd № 91807; Zayavl. 09.10.2009; Opubl. 25.08.2010, Byul. 16 (in Ukrainian).

Sidorenko, R.P., Korneyev, A.V. (2010). Intensivnost' rosta i biokhimicheskiye pokazateli krovi porosyatsosunov pri vvedenii $\mathrm{V}$ ratsion suporosnykh $\mathrm{i}$ podsosnykh svinomatok L-karnitina. Svinovodstvo, 3, 32-35 (in Russian).

Received 29.09.2017

Received in revised form 26.10.2017 Accepted 3.11.2017 